\title{
The Countermeasure Research on the Agricultural Supply-side Structural Reform in Liaoning Province*
}

\author{
Yanbo Zhou \\ College of Economics and Management \\ Shenyang Agricultural University \\ Shenyang, China \\ Qizhe Wang \\ College of Economics and Management \\ Shenyang Agricultural University \\ Shenyang, China
}

\author{
Wen Shi** \\ College of Economics and Management \\ Shenyang Agricultural University \\ Shenyang, China \\ **Corresponding Author \\ Fangwei Zhang \\ College of Economics and Management \\ Shenyang Agricultural University \\ Shenyang, China
}

\begin{abstract}
In 2017, the No 1 Central Document promoted the agricultural supply-side structural reform as the main line of current agricultural and rural work and carried out the toplevel design at the national level, clarified the main objectives, main direction, key tasks and specific measures of the reform. Based on the theoretical analysis of the agricultural supplyside structural reform, this study uses a large amount of data and financial policy to analyze the status quo of the structural reform of the agricultural supply side in Liaoning Province. In addition, the problems existing in agricultural supply-side structural reform are analyzed from aspects of the policy orientation of financial support to agriculture, agricultural "three subsidies" mode of supporting agriculture, the restrictive factors of agricultural supply-side structural reform, and agricultural credit guarantee system. Based on these, the author put forward some policy suggestions.
\end{abstract}

Keywords-agricultural supply-side reform; agricultural structure introduction

\section{INTRODUCTION}

In 2007, the No 1 Central Document "a series of opinions on deepening supply-side structural reform in agriculture and accelerating the cultivation of new driving forces for agricultural and rural development" were highlighted. The document closely follows the two sections of "Agricultural Supply Side Structure Adjustment + Reform" to make a layout, and carried out the top-level design at the national level, clarified the main objectives, main direction, key tasks and specific measures of the reform. Acting on the supply side and promoting major reforms to solve major structural problems is a long-term strategic measure taken by the CPC central committee and the state council, taking into account the changing international and domestic situation and the overall situation of economic and social development. The

*Sponsors: The research was sponsored by the education department project of Liaoning Province ((Project No. WSNZD201701), the Innovation of college students of Liaoning Province ((Project No. 201810157206). agricultural supply-side structural reform is not only an important part of the central government's efforts to promote supply-side structural reform, but also the basic support for ensuring the smooth progress of structural reformation in other fields. It not only a matter of the goal of agricultural modernization, but also affects the overall situation of constructing a moderately prosperous society in all respects on schedule.

The agriculture in Liaoning has entered a profound transition period, and the long-term problem of total shortage has been significantly alleviated. The supply and demand of agricultural products has changed from a long-term shortage to a gross balance. However, after Liaoning's agricultural development has entered the window period of strategic leap, the deep-seated contradictions of supply-side structure have begun to emerge. This will inevitably require Liaoning to push forward agricultural supply-side structural reform. In the future, the structure of agricultural products should be changed from production-oriented to consumption-oriented, and the policy goal should be changed from "maintaining growth" to the improvement the core competitiveness and quality efficiency of agriculture.

\section{CURRENT SituAtion OF AgRICULtURE SUPPly-SIDE REFORM IN LIAONING}

\section{A. Changes in the Structure of Agricultural Industries}

As shown in "Table I", it can be seen that the total sown area of crops in Liaoning province increases with the passage of time. In 2009 it exceeded 4,000 hectares for the first time. After 2012, the planting area of crops showed a downward trend, from 4361.3 thousand hectares in 2012 to 4064.1 thousand hectares in 2016, and the total planting area decreased by 297.2 thousand hectares, with a decreasing rate of $6.8 \%$

In terms of the total sown area, grain crops accounted for an absolute proportion, with the lowest annual sown area 
accounting for $72.8 \%$ and the highest year as high as $85.2 \%$. Since 2011, the area planted by grain crop has been growing, but it has not reached more than $80 \%$. Economic crop takes up a small proportion in the total seeding area of Liaoning province and changes greatly. From 2000 to 2003, the proportion of economic crops has been increasing, up to 9.9\%. However, in 2006 and 2007, the planting area of economic crops decreased dramatically, and only 118.7 thousand hectares were planted in 2007. Since 2008, the planting area and proportion of economic crops have increased, but not much. In terms of other crops, sown area shows a trend of decrease. Especially since 2011, sown area has been decreasing, accounting for $4.3 \%$ from $17.4 \%$ in 2011 to $13.1 \%$ in 2016 .

From the data of 2000-2016, it can be seen that in Liaoning area, grain crops have an absolute advantage in the total planting area of crops, followed by other crops and the least economic crops. In addition, although the change value of sown area of grain crops is large, the proportion in total area does not change much.

TABLE I. Changes of Agricultural Industrial Structure FROM 2000 TO 2016

\begin{tabular}{|l|l|l|l|l|l|l|l|}
\hline Year & $\begin{array}{c}\text { Total } \\
\text { area of } \\
\text { crop } \\
\text { plantin } \\
\text { g (1000 } \\
\text { ha) }\end{array}$ & $\begin{array}{c}\text { Food } \\
\text { crops } \\
\mathbf{( 1 0 0 0}\end{array}$ & $\begin{array}{c}\text { Proportio } \\
\text { n of total } \\
\text { seeding } \\
\text { area (\%) }\end{array}$ & $\begin{array}{c}\text { Econ } \\
\text { omic } \\
\text { crops }\end{array}$ & $\begin{array}{c}\text { Proportio } \\
\text { n of total } \\
\text { seeding } \\
\text { area (\%) }\end{array}$ & $\begin{array}{c}\text { Othe } \\
\text { r } \\
\text { crops } \\
\mathbf{( 1 0 0 0} \\
\text { ha) })\end{array}$ & $\begin{array}{c}\text { Proportio } \\
\text { n of total } \\
\text { seeding } \\
\text { area (\% }\end{array}$ \\
\hline 2000 & 3622.0 & 2858.6 & 78.9 & 248.0 & 6.8 & 515.4 & 14.2 \\
\hline 2001 & 3559.9 & 2758.1 & 77.5 & 279.9 & 7.9 & 522.0 & 14.7 \\
\hline 2002 & 3577.0 & 2658.6 & 74.3 & 327.8 & 9.2 & 590.6 & 16.5 \\
\hline 2003 & 3476.6 & 2563.6 & 73.7 & 344.6 & 9.9 & 568.4 & 16.3 \\
\hline 2004 & 3666.5 & 2965.8 & 80.9 & 242.2 & 6.6 & 458.5 & 12.5 \\
\hline 2005 & 3801.0 & 3179.7 & 83.7 & 199.4 & 5.2 & 421.9 & 11.1 \\
\hline 2006 & 3627.2 & 3089.7 & 85.2 & 118.6 & 3.3 & 418.9 & 11.5 \\
\hline 2007 & 3703.9 & 3127.2 & 84.4 & 118.1 & 3.2 & 458.6 & 12.4 \\
\hline 2008 & 3946.4 & 3035.9 & 76.9 & 320.7 & 8.1 & 589.8 & 15.0 \\
\hline 2009 & 4064.7 & 3124.1 & 76.9 & 313.6 & 7.7 & 627.0 & 15.4 \\
\hline 2010 & 4184.9 & 3179.3 & 76.0 & 380.8 & 9.1 & 624.8 & 14.9 \\
\hline 2011 & 4356.2 & 3169.8 & 72.8 & 428.3 & 9.8 & 758.1 & 17.4 \\
\hline 2012 & 4361.3 & 3217.3 & 73.8 & 390.7 & 9.0 & 753.3 & 17.3 \\
\hline 2013 & 4208.8 & 3226.4 & 76.7 & 368.4 & 8.8 & 614.0 & 14.6 \\
\hline 2014 & 4164.1 & 3235.1 & 77.7 & 327.7 & 7.9 & 601.3 & 14.4 \\
\hline 2015 & 4219.8 & 3297.4 & 78.1 & 296.9 & 7.0 & 625.5 & 14.8 \\
\hline 2016 & 4064.1 & 3231.3 & 79.5 & 302.1 & 7.4 & 530.6 & 13.1 \\
\hline
\end{tabular}

\section{B. Cost Analysis of Different Crops}

As can be seen from "Table II", the total cost of grain corn increases year by year with the progress of grain crops, but not much. The total cost of soybeans dropped, most notably in 2014, with a drop of 220.32 Yuan/mu compared to 1003.5 / $\mathrm{mu}$ in 2013, and remained at a low level in 2014 to 2016.The total cost of potatoes changed little, with an average cost of $1455.7 \mathrm{Yuan} / \mathrm{mu}$ from 12 to 16 years.

In terms of economic crops, the total cost of peanuts fluctuated slightly, but remained stable overall. In terms of economic crops, the total cost of peanuts fluctuated slightly, but remained stable overall. The total cost of vegetables is highest among all crops because the multi-cropping index of vegetables is relatively high as compared to a one-year cultivation system for other crops. The increase in the total cost of vegetables was also the most obvious, increasing by $39.5 \%$ from 3,644.72 Yuan/mu in 2012 to 5,084.54 Yuan/mu in 2016 .

TABLE II. TOTAL COST ANALYSIS OF DifFERENT CROPS

\begin{tabular}{|l|c|c|c|c|c|}
\hline \multicolumn{1}{|c|}{ Year } & $\mathbf{2 0 1 2}$ & $\mathbf{2 0 1 3}$ & $\mathbf{2 0 1 4}$ & $\mathbf{2 0 1 5}$ & $\mathbf{2 0 1 6}$ \\
\hline Total cost of corn & 923.05 & 1003.50 & 1067.12 & 1070.6 & 1027.61 \\
\hline Total soybean cost & 923.05 & 1003.50 & 783.18 & 768.94 & 770.01 \\
\hline Total potato cost & 1462.21 & 1474.01 & 1423.35 & 1409.81 & 1449.16 \\
\hline Total peanuts & 1054.34 & 1263.61 & 1068.47 & 1159.92 & 1064.56 \\
\hline Total vegetable cost & 3644.72 & 4050.94 & 4133.88 & 4345.30 & 5084.54 \\
\hline
\end{tabular}

\section{The Adoption of Agricultural Green Production Mode}

$\mathrm{U}$ Liaoning province organized and implemented zero growth of pesticide and fertilizer use, strengthened reduction and efficiency increase and promoted green and environmental protection technology, and completed annual planning and control indicators.

Meanwhile, Liaoning province promoted the trial of black land protection and utilization in northeast China, and the financial department implemented the subsidy project of farmland quality protection and improvement. The opinions on promoting the comprehensive utilization of crop straw were introduced and the pilot work on the comprehensive utilization of crop straw was carried out. A large and medium-sized biogas project, three model towns for energy utilization of straw and 10 comprehensive rural energy pilot projects were built.

The financial department of Liaoning province completed the issuance of 4.08 billion Yuan of agricultural land protection subsidies. The goal of "one control, two reductions and three basic" has achieved remarkable results, with zero growth of fertilizers and pesticides, and the comprehensive utilization rate of crop straw reaching $84 \%$. The agricultural and rural ecological environment has been continuously improved, and agricultural green development has been steadily promoted. 


\section{The Problems Existing IN THE Agriculture SUPPLY-SIDE REFORM IN LIAONING}

\section{A. The Problems Existing in the Adjustment of Agricultural Structure}

Policy control reduces the area, but not necessarily the corn area. On the one hand, corn is the largest grain crop in Liaoning province. Both in planting area and output, it is far more than other crops. Farmers have been used to planting corn, and it is very difficult to reduce the planting of corn on a large scale in a short time. Moreover, for most farmers, the operation of planting corn is simple, the cost is low, and the difficulty of field management is small, which is beneficial to some farmers who have a small family population and are older. At the same time, the high planting cost, great technical difficulty and unpredictable market situation of vegetables, fruits, grains and other crops have affected the enthusiasm of farmers to transform crops.

On the other hand, corn is still subsidized even though the reserve policy is abolished. In addition, with the improvement of the structure of maize varieties and the improvement of the operating rate of processing enterprises, the corn market is gradually improving, and the planting of corn is still profitable, so the planting intention of corn will not fade quickly. It is possible, instead, that as corn prices rise, and some farmers will even expand their acreage.

\section{B. Under Great Pressure to Destock, There Is a Serious Backlog of Corn}

Corn reserve policy has been implemented for eight consecutive years, which makes corn stocks abundant. An increase in imports has also squeezed the corn market over the years. In 2015, the data showed that the inventory was conservatively estimated at over 200 million tons. Despite the cancellation of the reserve policy in 2016 and 2017, the import quantity of corn and its substitutes has also been reduced, but there is still a very large supply and demand gap compared with the limited demand.

Through the national series of policies, although the planting area of corn has decreased, the effect of the policies remains to be investigated, so the pressure of corn inventory reduction in 2018 should not be underestimated. Through the national series of policies, although the planting area of corn has decreased, the effect of the policies remains to be investigated, so the pressure of corn inventory reduction in 2018 should not be underestimated. Therefore, it can be predicted that the price of corn will be affected by excessive inventory, and it is difficult to return to the market price when the storage policy was implemented.

\section{Agricultural Product Price Is Lower and Farmer's Income Difficulty Is Increased}

The agricultural product stays in the primary product stage which the added value is low, and the farmer increases the income difficulty. The agricultural product stays in the primary product stage the added value is low, the farmer increases the income difficulty. In the development process of agricultural industry, there are two problems: first, the agricultural industry itself lacks the ability of fine processing, and the degree of integration with the second and third industries is relatively low, and the comprehensive ability is not good; Second, the ability to serve the agricultural industrial chain is insufficient, agricultural product circulation cost is high.

\section{The Restrictive Factors of Agricultural Supply-side Structural Reform}

First, the basic conditions of agricultural production are still weak, with large scale of traditional agriculture, weak disaster-resistance capability and tightening resource and environment constraints. Second, the adjustment of agricultural structure has entered a crucial stage; the market and technical service system are not perfect enough. Some business entities are still confused about what to adjust and how to adjust it. The risk of agricultural market price fluctuation is increased, and the dynamic mechanism of "active adjustment" has not been established yet. Third, the cost of agricultural production is still high, the material input such as the means of production is easy to rise but hard to fall, and the characteristic agricultural products still have the problem of "special but not excellent, special but not strong": The middle and high grade, famous brand produce is not much, brand cultivation is insufficient, agricultural science and technology innovation ability is not strong. Fourth, the overall level of agricultural product processing industry is not high, and the abundant agricultural resource advantages have not been transformed into economic advantages through the development of processing industry, especially there is still a large gap compared with developed provinces in China. There are problems such as small scale of agricultural products processing enterprises, insufficient industrial agglomeration, low level of intensive processing, backward level of technical equipment and low degree of industrial integration

\section{Conclusion And Suggestions}

This paper elaborated on the basic features of the supply side of agriculture and pointed out that its problems lie in the lag of evolution of supply-side systems. From the perspective of deepening the reform, this paper also put forward some suggestions for the current supply-side structural reform of China's agriculture.

\section{A. Improving the System of Subsidies for Agricultural Producers}

The price of corn has dropped sharply, which has a great impact on farmers' planting income. Although China has established the corn and soybean producer subsidy system, it needs to be improved. One is that the subsidy quota cannot make up for the impact of the falling price of corn on farmers' income. Second, farmers in other main production areas are difficult to obtain subsidies, so income loss cannot make up. Third, there is no coordination between corn producer subsidies and soybean price subsidies, which is not conducive to the structural adjustment of corn producing areas. It is suggested to consider the relationship between corn and soybean price ratio as a whole, improve the subsidy 
mechanism, increase the amount of subsidy and expand the scope of subsidy, so as to ensure that farmers' income does not decline due to the price drop.

\section{B. Continuing to Implement a Proactive Fiscal Policy}

Fiscal policy has done a lot to support the "three goes, one drop, one supplement", especially in supporting poverty alleviation. In 2017, the central government's special fund for poverty alleviation increased by $30.3 \%$ to support targeted poverty alleviation, targeted poverty alleviation, support for deepening supply-side structural reform in agriculture, support for energy conservation and environmental protection, and so on. For Liaoning province, the path of agricultural supply-side reform is a long and arduous task, which needs the government's strong support.

\section{Increasing Support for New Business Entities}

In the case of a sharp decline in the price of corn, the higher land transfer fees put great pressure on new operators such as large grain growers. Large losses of great grain growers in many places have occurred, and some even abandoned their farmland at the break of the contract. It is suggested to attach great importance to the difficulties faced by the development of new business entities and take effective measures to properly support them.

\section{Innovating Fiscal Input Methods and Activating Leverage for Supply-side Structural Reform}

Financial subsidies should be based on the evaluation results of project operation performance to establish a dynamic subsidy mechanism, which should be classified into government budgets at the same level, taken into consideration in medium and long-term fiscal planning to ensure the government's performance.

\section{REFERENCES}

[1] Chen Yongfu, Han Xinru. Analysis of the causes of excess corn market in China under the background of globalization [J]. Exploration of economic problems, 2016(3):164-171.

[2] Chen Yesheng, pan Huabin. Thoughts and direction of corn supplyside structural reform [J]. Outlook of agricultural production, 2016(8):35-37.

[3] Cui Ningbo, Zhang Zhengyan. Influence factors and income effect of corn planting structure adjustment under the cancellation of the reserve policy — based on the analysis of survey data in Liangdao region of Heilongjiang province [J]. Business research, 2017(11):153163.

[4] Guo Qinghai. Analysis of difficulties in supply-side structural reform of corn industry [J]. Agricultural economy and management, 2017(1):5-11.

[5] Kong Xiangzhi. Basic connotation and policy recommendations of agricultural supply-side structural reform [J]. Reform, 2016(2):104115.

[6] Li Xiaoyun, Huang Malan, Zeng Llinlin and Zhang Anlu. Structural change analysis of grain growth in the middle reaches of the Yangtze river - analysis and verification based on shift-share model [J], agricultural technical economy, 2016(8):85-93

[7] He Jing Guo Pei Zhou Yuqing,Rural financial reform and development under the background of agricultural supply side reform:
Summary of the 11th China Rural Financial Development Forum[J], Agricultural economic problems, 2018 (01):127-131.

[8] Camille Saint-Macary, Alwin Keil,Manfred Zeller,Franz Heidhues, Pham Thi My Dung Land titling policy and soil conservation in the northern uplands of Vietnam[J] .. Land Use Policy. 2009 (2).

[9] De Janvry,Alain,Kyle Emerick,Marco, Gonzalez-Navarro,Elisabeth Sadoulet. Delinking Land Rights from Land Use:Certification and Migration in Mexico[J]. The American Economist. 2015(09):15-18.

[10] Huang Zuhui, Fu Linlin, Li Haitao. Supply-side Structural Reform of China's Agriculture: Retrospect,Problemsand Reforms[J]. Journal of Nanjing Agricultural University (social science edition) 2016,16 (06): $1-5+152$.

[11] Demetris Psaltopoulos. Causes and Impacts of Agricultural Structures[J] . European Review of Agricultural Economics. 2008 (2):74-78.

[12] Luo Fumin, The Influence of Urbanization on Agricultural SupplySide Structure Change - Empirical Analysis Based on Distributed Lag Model[J]. Journal of Nanjing Agricultural University (social science edition) 2016, 16 (06): 1-5+152.

[13] Nicola Cetorelli,Philip E. Strahan,.Finance as a Barrier to Entry: Bank Competition and Industry Structure in Local U.S. Markets[J] The Journal of Finance. 2006 (1):25-26. 